\title{
The effect of non-genetic factors on the birth weight of Romanov sheep
}

\author{
Ivan Vlahek ${ }^{1 *}$, Anamaria Ekert Kabalin ${ }^{1}$, Sven Menčik ${ }^{1}$, Maja Maurić Maljković1, \\ Aneta Piplica ${ }^{1}$, Hrvoje Kabalin ${ }^{2}$, Juraj Šavorićc ${ }^{3}$, and Velimir Sušić ${ }^{1}$ \\ ${ }^{1}$ Department of Animal Breeding and Livestock Production, Faculty of Veterinary Medicine, University of Zagreb, \\ Zagreb, Croatia \\ ${ }^{2}$ Jastrebarsko Veterinary Station, Pisarovina clinic, Pisarovina, Croatia \\ ${ }^{3}$ Reproduction and Obstetrics Clinic, Faculty of Veterinary Medicine, University of Zagreb, Zagreb, Croatia
}

VLAHEK, I., A. EKERT KABALIN, S. MENČIK, M. MAURIĆ MALJKOVIĆ, A. PIPLICA, H. KABALIN, J. ŠAVORIĆ, V. SUŠIĆ: The effect of non-genetic factors on the birth weight of Romanov sheep. Vet. arhiv 91, 615-624, 2021.

\section{ABSTRACT}

The aim of this study was to analyse the non-genetic factors influencing the birth weight of Romanov lambs, and to determine which of them may be a useful source of information in the selection of female lambs for replacement. The study included 1712 lambs born in the period from 2016 to 2019. The linear model used in birth weight estimation included: birth type, sex, parity, year of birth, season of birth, and breeding group as fixed factors. Year of birth $\mathrm{x}$ season of birth interaction was also included in the model. All factors, except the season of birth, significantly affected birth weight $(\mathrm{P}<0.05)$. Birth weight decreased significantly $(\mathrm{P}<0.05)$ with increasing birth type and singles, twins, triplets and quadruplets weighing $4.11 \pm 0.07,3.56 \pm 0.05,3.07 \pm 0.05$ and $2.66 \pm 0.08 \mathrm{~kg}$, respectively. Male lambs $(3.44 \pm 0.05 \mathrm{~kg})$ were significantly $(\mathrm{P}<0.05)$ heavier than female lambs $(3.25 \pm 0.05 \mathrm{~kg})$. The lightest lambs $(2.99 \pm$ $0.05 \mathrm{~kg}$ ) were born in the first litter, after which the birth weight gradually increased up to the sixth litter (3.54 \pm 0.10 $\mathrm{kg})$. Litter weight showed a nonlinear increase with an increase in birth type $(\mathrm{P}<0.05)$. The birth weight of female lambs from litters of twins and triplets with different ratios of male and female lambs did not differ significantly $(\mathrm{P}>0.05)$. Variations in birth weight are influenced by non-genetic factors, with birth type, sex, and parity being the most important. These factors should be considered in breeding and selection programs for lamb meat production, where fertility and growth traits have the key role.

Key words: birth weight; litter weight; non-genetic factors; Romanov sheep; selection

\section{Introduction}

Improving animal productivity is based on the variability of traits important for a particular breeding goal and on the selection of animals with desirable phenotypes for these traits. Besides reproductive traits, growth traits are the main determinants of lamb production efficiency (WOLFOVÁ et al.,

2011; ASSAN, 2020). The earliest measurable growth trait is birth weight (BW). It is an important predictor of the health status of a lamb (CHRISTLEY et al., 2003) and EVERETT - HINCKS et al. (2014) suggest that selection for BW would have a direct effect on survival rates in lambs. Furthermore,

\footnotetext{
*Corresponding author:

Ivan Vlahek, DMV, Department of Animal Breeding and Livestock Production, Faculty of Veterinary Medicine University of Zagreb, Heinzelova 55, Zagreb, Croatia, Phone: +385 2390 221; E-mail: ivan.vlahek@vef.hr
} 
BW is correlated with weaning weight and weight at puberty (SAFARI et al., 2005), which makes it particularly useful in selection of lambs for replacement.

The genetically determined variations in the BW of lambs are most often associated with differences between breeds. The existence of within breed variations in BW supports the fact that nongenetic factors also influence this trait. Therefore, adjustment for non-genetic factors contributes to a more accurate estimation of BW (MAHALA et al., 2019). Non-genetic factors affecting BW include: birth type, sex, parity, nutrition, the body weight and condition of the dam at mating, year of birth, season of birth and production system (NOTTER et al., 1991; ASSAN, 2020).

Birth type is the most important non-genetic factor influencing BW. The general trend is that BW of lambs decreases with an increase in birth type, and investigations of different sheep breeds (SUŠIĆ et al., 2005; GOOTWINE and ROZOV, 2006; PETROVIĆ et al., 2009; MOHAMMADI et al., 2010; MELLADO et al., 2016) showed significant differences in BW between lambs born in different sized litters. In a meta-analysis, GOOTWINE (2005) reported BW of lambs from twins, triplets, and quadruplets to be $83 \%, 70 \%$, and $63 \%$ of that of singles, respectively. However, ASSAN and MAKUZA (2005) found that singles and twins of Mutton Merino and Dorper breeds did not differ significantly in BW.

The significant effect of the lamb's sex on BW was found by MOHAMADI et al. (2010), THIRUVENKADAN et al. (2008), CHNITER et al. (2011), RAHIMI et al. (2014) and MELLADO et al. (2016). In general, male lambs tend to be heavier than female lambs. These differences can be explained by the different hormonal profiles of male and female fetuses (GARDNER et al., 2007). However, some reports (ASAN and MAKUZA, 2005; PETROVIĆ et al., 2011) found these differences to be non-significant.

The lowest BW of lambs in the first litter is a general trend. In most sheep, physical development is not fully completed at the time of the first mating and some of the nutrients that would otherwise be intended for fetal development are used for maternal growth. The lower BW of lambs in the first litter compared to higher parity litters was confirmed by THIRUVENKADAN et al. (2008), GOOTWINE and ROZOV (2006) and CHNITER et al. (2011).

Variations in BW regarding birth type can also be observed at the level of litter weight (LW). FREETLY and LEYMASTER (2004) reported a nonlinear increase in LW with an increase in birth type.

BW variations are particularly interesting in hyperprolific breeds such as Romanov sheep. This breed is most commonly used in crossbreeding to improve fertility, and as a pure breed for meat production. Despite its popularity in lamb production, there are only a few reports (EL - KSAS et al., 2018; MURPHY et al., 2020) on the influence of non-genetic factors on the BW of Romanov sheep.

The objective of this study was to assess the influence of non-genetic factors on BW and LW in Romanov sheep, and to determine which of them may be a useful source of information in the selection of female lambs for replacement.

\section{Materials and methods}

Animals and general management. The data for this study were derived from one Romanov sheep farm in Croatia. The breeding flock was kept under semi-intensive production system and consisted of 275 sheep and seven rams of the Romanov breed. The production system was based on accelerated lambing with continuous mating, aimed to produce lambs for slaughter at the age of approximately 90 days with a body weight of about 25 kilograms, as well as breeding rams and ewe lambs. On the farm, sheep were kept in small groups (flocks) with about 40 sheep and one ram per group. Groups were formed by random allocation of selected ewe lambs and young rams, and inbreeding was strictly avoided. Once formed, the groups were permanent, meaning that the rams were always kept with the same group of sheep and there was no possibility of rams mating with ewes from different groups. The rams used were of different bloodlines. Before lambing, the sheep were separated into individual pens where admission of newborn lambs (drying 
and vitality testing) and weighing were performed immediately after birth. After three to four days spent in individual pens, the ewes and lambs were returned to their group (with other ewes and the ram). Throughout the year, the sheep were fed a commercial feed mixture with $16 \%$ protein, and meadow hay ad libitum.

Recording and definition of variables. A total of 1712 birth weight (BW) records from 2016 to 2019 were used. BW was recorded by a suspending scale. Parity, birth type, sex of lambs, year of birth and date of birth were determined from reproduction cards. Lambing seasons were derived from the date of birth and were defined as follows: spring-summer (April to September) and autumn-winter (October to March). Lambs born in a particular breeding group were assigned a group number (1-7). Categorical variables (considered as non-genetic factors) were defined as follows: parity (1-6), birth type (singlequadruplet), sex (male, female), breeding group (1-7), year of lambing (2016 - 2019) and season of lambing (spring-summer, autumn-winter).

For analysis of the differences in the BW of female lambs, twin and triplet litters were divided into categories based on the number of female lambs per litter (twins: one or two, triplets: one, two or three female lambs in the litter). Quadruplets were rare and therefore excluded from this analysis. Litter weight (LW) was calculated as the sum of birth weights of all the lambs from the litter.

Statistical analysis. Multiple linear regression analysis was used to examine the influence on BW of parity, birth type, sex, breeding group, year of birth, season of birth and year of birth $\mathrm{x}$ season of birth interaction.

The fixed effects model used for data analysis was as follows:

$\mathrm{Y}_{\mathrm{ijklmn}}=\mu+\mathrm{P}_{\mathrm{i}}+\mathrm{T}_{\mathrm{j}}+\mathrm{S}_{\mathrm{k}}+\mathrm{A}_{1}+\mathrm{B}_{\mathrm{m}}+\mathrm{G}_{\mathrm{n}}+\mathrm{A}_{1} \times \mathrm{B}_{\mathrm{m}}+\varepsilon_{\mathrm{ijklmn}}$ where:

$\mathrm{Y}_{\mathrm{ijklmn}}=$ phenotypic value of $\mathrm{BW} ; \mu=$ overall population mean; $P_{i}=$ fixed effect of $i^{\text {th }}$ parity; $T_{j}=$ fixed effect of $j^{\text {th }}$ birth type; $\mathrm{S}_{\mathrm{k}}=$ fixed effect of $\mathrm{k}^{\text {th }}$ sex of lamb; $\mathrm{A}_{1}=$ fixed effect of $1^{\text {th }}$ year of birth; $B_{m}=$ fixed effect of $\mathrm{m}^{\text {th }}$ season of birth; $\mathrm{G}_{\mathrm{n}}=$ fixed effect of $\mathrm{n}^{\text {th }}$ breeding group; $A_{1} \times \mathrm{B}_{\mathrm{m}}$ $=$ interaction of $1^{\text {th }}$ year of birth and $\mathrm{m}^{\text {th }}$ season of birth; $\varepsilon_{\mathrm{ijklmn}}=$ residual error.
Analysis of variance was used to test for significant influence of fixed factors. The significance of differences between individual groups within the same fixed factor was tested by Tukey's post-hoc test.

Differences in the BW of female lambs and LW were examined with one-way ANOVA and Tukey's post-hoc test. All results were tested at the significance level of $\mathrm{P}<0.05$. All statistical analyses were performed using the statistical program TIBCO Statistica ${ }^{\circledR}$ v 13.5.0. (STATISTICA, 2020).

\section{Results}

The average BW of the whole examined population of 1712 lambs was $3.23 \pm 0.68 \mathrm{~kg}$ (Table $1)$. The least square means and standard error for the BW, according to the level of fixed factors, are shown in Table 2. Significant differences $(\mathrm{P}<0.05)$ in the BW were recorded between all groups according to the birth type. The largest difference between two successive birth types was recorded between singles and twins, and was $0.55 \mathrm{~kg}$. The difference between singles and quadruplets was $1.55 \mathrm{~kg}$. The BWs of lambs from twin, triplet and quadruplet litters were $87 \%, 75 \%$ and $65 \%$ of the birth weight of singles, respectively. Male lambs $(3.44 \mathrm{~kg})$ were on average $0.19 \mathrm{~kg}(\mathrm{P}<0.05)$ heavier than female lambs $(3.25 \mathrm{~kg})$. BW increased significantly $(\mathrm{P}<0.05)$ with the increase in parity, so lambs from the first parity had an average weight of $2.99 \pm 0.05 \mathrm{~kg}$ and lambs from the sixth parity 3.54 $\pm 0.10 \mathrm{~kg}$. The BW of lambs from the second and third parities were significantly $(\mathrm{P}<0.05)$ different from the BW of lambs in other parities. The largest difference between two successive parities was between the second and the first parities (Fig. 1). Significant differences were also observed in the BW of lambs in relation to the breeding group $(\mathrm{P}<0.05)$. The largest difference recorded was between lambs originating from the first group and lambs from the fourth group $(0.24 \mathrm{~kg})$. Lambs born in 2016 were significantly $(\mathrm{P}<0.05)$ heavier than lambs born in 2017-2019. Differences between seasons were not significant $(\mathrm{P}>0.05)$. Considering interaction between the year and season of birth, lambs born in the spring-summer season of 2016 were significantly $(\mathrm{P}<0.05)$ heavier than lambs 
I. Vlahek et al.: The effect of non-genetic factors on the birth weight of Romanov sheep

Table 1. Descriptive statistics for the birth weight of Romanov lambs

\begin{tabular}{|l|c|c|c|c|c|c|}
\hline Variable & $\mathrm{N}$ & Mean & S.D. & Min. & Max. & C.V. (\%) \\
\hline Birth weight $(\mathrm{kg})$ & 1712 & 3.23 & 0.68 & 1.40 & 6.16 & 21.14 \\
\hline
\end{tabular}

Table 2. Influence of non-genetic factors on the birth weight of Romanov lambs. Results are presented as least square means and standard error $(\mathrm{LSM} \pm \mathrm{SE})$.

\begin{tabular}{|c|c|c|c|}
\hline Fixed factor & Level of factor & $\mathrm{N}$ & $\mathrm{LSM} \pm \mathrm{SE}(\mathrm{kg})$ \\
\hline \multirow{4}{*}{ Birth type } & Single & 116 & $4.11 \pm 0.07^{\mathrm{a}}$ \\
\hline & Twin & 920 & $3.56 \pm 0.05^{\mathrm{b}}$ \\
\hline & Triplet & 594 & $3.07 \pm 0.05^{\mathrm{c}}$ \\
\hline & Quadruplet & 82 & $2.66 \pm 0.08^{\mathrm{d}}$ \\
\hline \multirow{2}{*}{ Sex } & Male & 873 & $3.44 \pm 0.05^{\mathrm{a}}$ \\
\hline & Female & 839 & $3.25 \pm 0.05^{b}$ \\
\hline \multirow{6}{*}{ Parity } & 1 & 385 & $2.99 \pm 0.05^{\mathrm{a}}$ \\
\hline & 2 & 503 & $3.35 \pm 0.05^{b}$ \\
\hline & 3 & 309 & $3.38 \pm 0.06^{b}$ \\
\hline & 4 & 283 & $3.44 \pm 0.07^{\mathrm{a}}$ \\
\hline & 5 & 138 & $3.40 \pm 0.08^{\mathrm{a}}$ \\
\hline & 6 & 94 & $3.54 \pm 0.10^{\mathrm{a}}$ \\
\hline \multirow{7}{*}{ Breeding group } & Group 1 & 360 & $3.48 \pm 0.05^{\mathrm{a}}$ \\
\hline & Group 2 & 378 & $3.31 \pm 0.05^{\mathrm{a}}$ \\
\hline & Group 3 & 361 & $3.42 \pm 0.05^{\mathrm{a}}$ \\
\hline & Group 4 & 268 & $3.24 \pm 0.06^{\mathrm{b}}$ \\
\hline & Group 5 & 80 & $3.39 \pm 0.09^{\mathrm{bc}}$ \\
\hline & Group 6 & 176 & $3.34 \pm 0.08^{\mathrm{bc}}$ \\
\hline & Group 7 & 89 & $3.27 \pm 0.10^{c}$ \\
\hline \multirow{4}{*}{ Year of birth } & 2016 & 232 & $3.71 \pm 0.12^{\mathrm{a}}$ \\
\hline & 2017 & 544 & $3.35 \pm 0.05^{b}$ \\
\hline & 2018 & 401 & $3.27 \pm 0.04^{b}$ \\
\hline & 2019 & 535 & $3.07 \pm 0.10^{b}$ \\
\hline \multirow{2}{*}{ Season of birth } & Spring-Summer & 487 & $3.46 \pm 0.08^{\mathrm{a}}$ \\
\hline & Autumn-Winter & 1225 & $3.24 \pm 0.04^{\mathrm{a}}$ \\
\hline \multirow{8}{*}{$\begin{array}{l}\text { Year of birth } \times \text { season of birth } \\
\text { interaction }\end{array}$} & $2016 \times \mathrm{S}-\mathrm{S}^{*}$ & 8 & $4.11 \pm 0.21^{\mathrm{a}}$ \\
\hline & $2016 \times \mathrm{A}-\mathrm{W}^{* * *}$ & 224 & $3.30 \pm 0.07^{\mathrm{bc}}$ \\
\hline & $2017 \times \mathrm{S}-\mathrm{S}$ & 206 & $3.37 \pm 0.07^{\mathrm{bc}}$ \\
\hline & $2017 \times \mathrm{A}-\mathrm{W}$ & 338 & $3.34 \pm 0.05^{\mathrm{b}}$ \\
\hline & $2018 \times \mathrm{S}-\mathrm{S}$ & 265 & $3.27 \pm 0.05^{\mathrm{b}}$ \\
\hline & $2018 \times A-W$ & 136 & $3.27 \pm 0.06^{b}$ \\
\hline & $2019 \times \mathrm{S}-\mathrm{S}$ & 8 & $3.10 \pm 0.20^{\mathrm{bc}}$ \\
\hline & $2019 \times A-W$ & 527 & $3.03 \pm 0.03^{c}$ \\
\hline
\end{tabular}

Least square means within factor with different superscripts differ significantly $(\mathrm{P}<0.05)$; $\mathrm{S}-\mathrm{S}^{*}$ - Spring-Summer season; A-W** - Autumn-Winter season 
Table 3. Variance analysis of birth weight

\begin{tabular}{|c|c|c|c|c|c|}
\hline Fixed factor & DF & MS & $\mathrm{F}$ & $\mathrm{P}$ & $\mathrm{R}^{2}(\%)$ \\
\hline Birth type & 3 & 55.92 & 178.87 & $<0.001$ & \multirow{7}{*}{$\begin{array}{c}33.79 \\
(\mathrm{P}<0.001)\end{array}$} \\
\hline Sex & 1 & 15.61 & 49.92 & $<0.001$ & \\
\hline Parity & 5 & 6.11 & 19.55 & $<0.001$ & \\
\hline Breeding group & 6 & 1.60 & 5.13 & $<0.001$ & \\
\hline Year of birth & 3 & 3.35 & 10.70 & $<0.001$ & \\
\hline Season of birth & 1 & 0.50 & 1.61 & 0.205 & \\
\hline $\begin{array}{l}\text { Year of birth } \mathrm{x} \text { season of birth } \\
\text { interaction }\end{array}$ & 3 & 1.48 & 4.73 & 0.003 & \\
\hline
\end{tabular}

Table 4. Litter weight $(\mathrm{kg})$ for different birth types

\begin{tabular}{|l|c|c|c|}
\hline \multirow{4}{*}{ Variable } & Birth type & $\mathrm{n}$ & Mean \pm SE $(\mathrm{kg})$ \\
\hline \multirow{4}{*}{ Litter weight } & Single & 115 & $3.98 \pm 0.08^{\mathrm{a}}$ \\
\cline { 2 - 4 } & Twin & 457 & $6.77 \pm 0.05^{\mathrm{b}}$ \\
\cline { 2 - 4 } & Triplet & 193 & $8.79 \pm 0.08^{\mathrm{c}}$ \\
\cline { 2 - 4 } & Quadruplet & 20 & $10.32 \pm 0.26^{\mathrm{d}}$ \\
\hline
\end{tabular}

Column means with different superscript letters differ significantly $(\mathrm{P}<0.001)$

Table 5. Litter weight (LW) and female lamb birth weight (BW) for different sex combinations in twin and triplet litters

\begin{tabular}{|l|c|c|c|c|}
\hline \multirow{3}{*}{ Birth type } & Sex combination within birth type & $\mathrm{n}$ & $\begin{array}{c}\text { LW } \\
\text { Mean } \pm \text { SE }(\mathrm{kg})\end{array}$ & $\begin{array}{c}\text { BW of female lambs } \\
\text { Mean } \pm \text { SE }(\mathrm{kg})\end{array}$ \\
\hline \multirow{4}{*}{ Twin } & Male-male & 135 & $6.86 \pm 0.10^{\mathrm{a}}$ & $/$ \\
\cline { 2 - 5 } & Male-female & 202 & $6.76 \pm 0.07^{\mathrm{a}}$ & $3.29 \pm 0.04^{\mathrm{a}}$ \\
\cline { 2 - 5 } & Female-female & 121 & $6.69 \pm 0.11^{\mathrm{a}}$ & $3.35 \pm 0.04^{\mathrm{a}}$ \\
\hline \multirow{4}{*}{ Triplet } & Male-male-male & 26 & $8.91 \pm 0.20^{\mathrm{b}}$ & $/$ \\
\cline { 2 - 5 } & Male-male-female & 76 & $8.90 \pm 0.14^{\mathrm{b}}$ & $2.68 \pm 0.06^{\mathrm{b}}$ \\
\cline { 2 - 5 } & Male-female-female & 69 & $8.79 \pm 0.12^{\mathrm{b}}$ & $2.85 \pm 0.05^{\mathrm{b}}$ \\
\cline { 2 - 5 } & Female-female-female & 23 & $8.34 \pm 0.20^{\mathrm{b}}$ & $2.80 \pm 0.05^{\mathrm{b}}$ \\
\hline
\end{tabular}

Column means with different superscript letters differ significantly $(\mathrm{P}<0.05)$ 


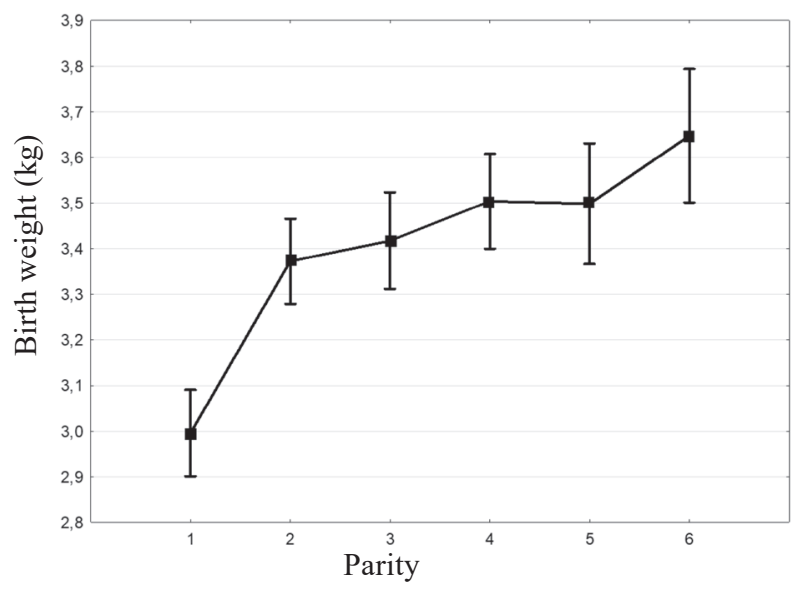

Fig. 1. Birth weight $(\mathrm{kg})$ in relation to parity. The results are presented as least square means and standard error $(\mathrm{LSM} \pm \mathrm{SE})$.

born in other years/seasons. Also, lambs born in the autumn-winter season of 2019 were significantly $(\mathrm{P}<0.05)$ lighter than lambs born in the autumnwinter season of 2017, the spring-summer season of 2018 , and the autumn-winter season of 2018.

Analysis of variance results are presented in Table 3. All fixed effects, except season of birth, significantly $(\mathrm{P}<0.05)$ contributed to the variability of the BW. The amount of variation in BW explained by the model was $33.79 \%\left(\mathrm{R}^{2}=0.3379, \mathrm{~F}(22,1689)\right.$ $=39.18, \mathrm{P}<0.001)$.

LW for different birth types is presented in Table 4. LW increased with the increase in birth type and all differences were significant $(\mathrm{P}<0.001)$. The observed increase was non-linear (Fig. 2). The

\section{Discussion}

The Romanov sheep originates from Russia and is considered unique in terms of its high fertility. According to the official data (MINISTRY OF AGRICULTURE, 2019), this breed is the most numerous imported (allochthonous) breed in Croatia, with 47 registered purebred flocks $(6.4 \%$ of the total breeding population). The breeding goal for Romanov sheep in Croatia is mainly focused on improving fertility and growth traits by within breed selection.

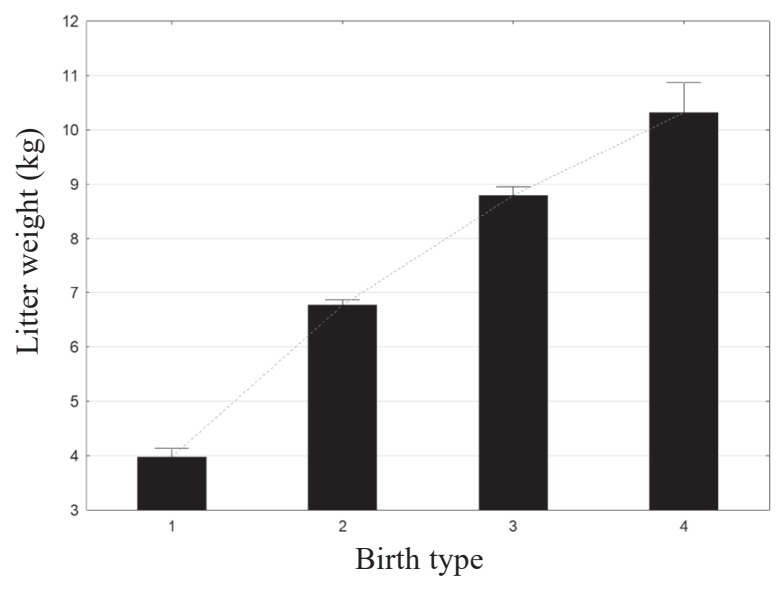

Fig. 2. Litter weight $(\mathrm{kg})$ in relation to birth type. The results are presented as mean and standard error $(\overline{\mathrm{X}}$ and $\mathrm{SE})$.

difference in LW between twins and singles was $2.79 \mathrm{~kg}$, between triplets and twins $2.02 \mathrm{~kg}$, and between quadruplets and triplets $1.53 \mathrm{~kg}$.

LW in twins and triplets according to the sex combination are presented in Table 5. Within both twin and triplet birth types LW tended to be higher when there were more male lambs in the litter. However, none of the differences were statistically significant $(\mathrm{P}>0.05)$. Nonsignificant differences $(\mathrm{P}>0.05)$ were observed between the BW of female lambs from different sex combinations within same birth type. The differences between the BW of female twin and triplet lambs were significant $(\mathrm{P}<0.05)$.

The most commonly analysed growth traits in lamb production are birth weight and weaning weight. The BW of lambs shows significant variations at inter- and within breed levels. The average BW of Romanov lambs in the present study was higher than the average value in studies of the same breed by EL - KSAS et al. (2018) and MURPHY et al. (2020). The variability in the BW of the studied lambs was relatively high (21.14\%), which is consistent with studies on Romanov sheep 
(MURPHY et al., 2020) and other breeds (MOUSA et al. 2013; BALTA and TOPAL, 2018) in which relative variability ranged from 15.75 to $28.41 \%$.

For assessing the contribution of non-genetic factors to within breed variability in the BW, a fixed effect model was applied that included birth type, sex, parity, year of birth, season of birth, year of birth x season of birth interaction, and breeding group as fixed factors. Analysis of variance confirmed that all fixed factors, except season of birth, were statistically significant. Factors with a major contribution to variations in BW were birth type, sex and parity, which is consistent with the results of similar studies conducted by MURPHY et al. (2020) and EL - KSAS et al. (2018) on Romanov sheep. In the present study, the amount of explained variance in $\mathrm{BW}$ was lower compared to the research by GBANGBOCHE et al. (2006) who obtained a coefficient of determination of $42 \%$. GOOTWINE and ROZOV (2006) obtained an even higher $\mathrm{R}^{2}$ (52\%), however, they also included gestation length as a covariable, month $\mathrm{x}$ parity interaction, and month $\mathrm{x}$ litter size interaction in the model.

Birth type often has a major influence on the BW of lambs. In general, the BW of lambs decreases as the number of lambs in the litter increases, and the main causes of this decrease are the limitation of uterine space and the decrease in the number of placentomes per fetus in multiparous litters (GREENWOOD et al., 2000). The extent of the decline depends on the prolificacy of the investigated sheep breed. In most low, medium or high prolific breeds, research has been focused on the ratio between twins and singles (GBANGBOCHE et al., 2006; GOOTWINE and ROZOV, 2006; MOHAMMADI et al. 2010; CHNITER et al. 2011; MAHALA et al., 2019), with differences in favour of singles ranging from 0.13 to $0.98 \mathrm{~kg}$. In hyperprolific breeds such as Romanov sheep, different categorizations of litter size are possible. MURPHY et al. (2020) list categories of $\leq 2,3$ and $4+$ lambs and report differences in birth weight of $0.59 \mathrm{~kg}$ (between $\leq 2$ and 3) and $0.40 \mathrm{~kg}$ (between 3 and $4+$ ). In the present study, the birth weights of lambs originating from twin, triplet and quadruplet litters was $87 \%, 75 \%$ and $65 \%$ of the birth weight of singles, respectively. These differences were systematically smaller compared to the results of a meta-analysis (GOOTWINE, 2005) which included many prolific and hyperprolific breeds.

In the present research, variations in $\mathrm{BW}$ regarding sex and parity followed common trends. Thus, our results confirmed the significantly $(\mathrm{P}<0.05)$ higher $\mathrm{BW}$ of male lambs, which is consistent with the results of studies conducted on several other breeds (GBANGBOCHE et al., 2006; RAHIMI et al., 2014; MELLADO et al., 2016). The difference between male and female lambs was $0.19 \mathrm{~kg}(6 \%)$ which is similar to the results reported for Romanov lambs by MURPHY et al. (2020). Also, in accordance with research conducted on different breeds (THIRUVENKADAN et al., 2008; GOOTWINE and ROZOV, 2006; CHNITER et al., 2011) the BW of Romanov lambs from the present research significantly $(\mathrm{P}<0.05)$ increased with parity. The largest difference between two successive lambings was $0.36 \mathrm{~kg}$ and was found between the second and first lambing. It should be pointed out that in the present study the BW of Romanov lambs increased constantly up to the sixth parity, which is similar to the results (fifth parity) obtained by MURPHY et al. (2020).

Differences in the BW of female lambs and the dynamics of LW increase as a function of the birth type were also analysed in this research. In the assessment of the female lambs' BW, the combination of sexes in litters of twins and triplets was taken into account. These differences were considered in the context of possible criteria for selection, which in the case of the hyperprolific Romanov breed usually involves selection of the heaviest lambs from multiparous litters. LW increases at a decreasing rate depending on the number of lambs per litter (FREETLY and LEYMASTER, 2004). This was also confirmed in the present study. The rate of increase in LW between successive birth types was as follows: 70\% increase in twins compared to singles, $30 \%$ increase in triplets compared to twins and $14 \%$ increase in quadruplets compared to triplets. A negative trend in LW was observed with the increase in the number of female lambs per litter in multiparous litters, but the results were not statistically significant $(\mathrm{P}>0.05)$. Also, there were no significant $(\mathrm{P}>0.05)$ 
differences between the BWs of twin and triplet female lambs born in litters with different ratios of male and female lambs.

This study showed the significant $(\mathrm{P}<0.05)$ influence of breeding group on the BW of lambs. Given that the sheep were kept in fixed groups and always with the same ram, some of the variability can be attributed to the ram. This hypothesis is supported by research conducted by GOOTWINE and ROZOV (2006) and ASSAN and MAKUZA (2005) where the ram significantly influenced variations in BW. However, the latter authors found that in one of the investigated breeds the ram did not have a significant effect on the same trait.

The year of birth and season within the year of birth had a significant $(\mathrm{P}<0.05)$ influence on $\mathrm{BW}$. Investigations of several breeds found similar findings (GBANGBOCHE et al., 2006; PETROVIĆ et al., 2011; MELLADO et al., 2016). Annual and seasonal variations in BW are usually caused by qualitative and quantitative fluctuations in herbage availability. However, the general management and nutrition in the sheep in the present investigation did not differ over the years. Therefore, a possible explanation may be that the environment and climatic conditions during mating and pregnancy differed between the seasons within the years, which ultimately resulted in significantly different birth weights (GARDNER et al., 2007). Indeed, ĐURIČIĆ et al. (2019) found a significant influence of rainfall and temperature on the reproductive traits of Romanov sheep in Croatia.

In conclusion, our investigation confirmed the significant influence of non-genetic factors on the BW of Romanov lambs. Among several possible non-genetic factors, the main sources of variability in their BW are birth type, sex and parity. These factors separately, but also in combination, can be important in setting the criteria for selecting new breeding females where the basic assumption is that they should originate from multiparous litters and have high BW.

\section{References}

ASSAN, N. (2020): Dam breed effect and other dam related non-genetic factors as determinants of growth traits in goats and sheep production. Sci. J. Rev. 9, 616-633.

DOI: 10.14196/sjr.v9i3.535

ASSAN, N., S. M. MAKUZA (2005): The effect of nongenetic factors on birth weight and weaning weight in three sheep breeds of Zimbabwe. Asian - Aust. J. Anim. Sci. 18, 151-157.

DOI: 10.5713 /ajas.2005.151

BALTA, B., M. TOPAL (2018): Regression tree approach for assessing effects of non-genetic factors on birth weight of Hemsin lambs. Alinteri journal of agricultural sciences 33, 65-73.

CHNITER, M., M. HAMMADI, T. KHORCHANI, R. KRIT, B. LAHSOUMI, M. BEN SASSI, R. NOWAK, M. BEN HAMOUDA (2011): Phenotypic and seasonal factors influence birth weight, growth rate and lamb mortality in D'man sheep maintained under intensive management in Tunisian oases. Small Rumin. Res. 99, 166-170. DOI:10.1016/j.smallrumres.2011.03.046

CHRISTLEY, R. M., K. L. MORGAN, T. D. H. PARKIN, N. P. FRENCH (2003): Factors related to risk of neonatal mortality, birth weight and serum imunoglobulin concentration in lambs in the UK. Prev. Vet. Med. 57, 209226.

DOI: 10.1016/s0167-5877(02)00235-0

ĐURIČIĆ, D., M. BENIĆ, I. ŽURA ŽAJA, H. VALPOTIĆ, M. SAMARDŽIJA (2019): Influence of season, rainfall and air temperature on the reproductive efficiency in Romanov sheep in Croatia. Int. J. Biometeorol. 63, 817-824.

DOI: $10.1007 / \mathrm{s} 00484-019-01696-\mathrm{Z}$

EL - KSAS, E. F., S. M. EL - KOMEY, M. A. SALLAM, A. S. KHATTAB (2018): Phenotypic and genotypic trends for body weights traits in Romanov sheep. J. Animal and Poultry Prod. 9, 325-330.

EVERETT - HINCKS, J. M., H. C. MATHIAS - DAVIS, G. J. GREER, B. A. AUVRAY, K. G. DODDS (2014): Genetic parameters for lamb birth weight, survival and death risk traits. J. Anim. Sci. 92, 2885-2895.

DOI: $10.2527 /$ jas2013-7176

FREETLY, H. C., K. A. LEYMASTER (2004): Relationship between litter birth weight and litter size in six breeds of sheep. J. Anim. Sci. 82, 612-618.

DOI: $10.2527 / 2004.822612 x$

GARDNER, D. S., P. J. BUTTERY, Z. DANIEL, M. E. SYMONDS (2007): Factors affecting birth weight in sheep: maternal environment. Reproduction 133, 297-307. DOI:10.1530/REP-06-0042

GBANGBOCHE, A. B., A. K. I. YOUSSAO, M. SENOU, M. ADAMOU - NDIAYE, A. AHISSOU, F. FARNIR, C. MICHAUX, F. A. ABIOLA, P. L. LEROY (2006): Examination of non-genetic factors affecting the growth 
performance of djallonke sheep in soudanian zone at the Okpara breeding farm of Benin. Trop. Anim. Health Prod. $38,55-64$.

DOI: $10.1007 / \mathrm{s} 11250-006-4231-9$

GOOTWINE, E. (2005): Variability in the rate of decline in birth weight as litter size increases in sheep. Anim. Sci. 81, 393-398.

DOI:10.1079/ASC41160393

GOOTWINE, E., A. ROZOV (2006): Seasonal effects on birth weight of lambs born to prolific ewes maintained under intensive management. Livest. Sci. 105, 277-283.

DOI:10.1016/j.livsci.2006.06.018

GREENWOOD, P. L., R. M. SLEPETIS, A. W. BELL (2000): Influences on fetal and placental weights during mid to late gestation in prolific ewes well nourished throughout pregnancy. Reprod. Fertil. Dev. 12, 149-156.

DOI: $10.1071 /$ rd00053

MAHALA, S., S. SAINI, A. KUMAR, L. L. L. PRINCE, G. R. GOWANE (2019): Effect of non-genetic factors on growth traits of Avikalin sheep. Small Rumin. Res. 174, 47-52.

DOI: 10.1016/j.smallrumres.2019.03.006

MELLADO, J., V. MARIN, J. L. REYES - CARRILLO, M. MELLADO, L. GAYTAN, M. DE LOS ANGELES DE SANTIAGO (2016): Effects of non-genetic factors on preweaning growth traits in Dorper sheep managed intensively in central Mexico. Ecosistemas y recursos agropecuarios 3, 229-235.

MINISTRY OF AGRICULTURE (2019): Sheep, goat and small animals breeding. In: Annual report for sheep, goats and small animals breeding in Republic of Croatia for 2018, Ministry of Agriculture, Vinkovci, Croatia.

MOHAMMADI, K., M. T. BEYGI NASSIRI, J. FAYAZI, H. ROSHANFEKR (2010): Investigation of environmental factors influence on pre-weaning growth traits in Zandi lambs. J. Anim. Vet. Adv. 9, 1011-1014.

DOI: $10.3923 /$ javaa.2010.1011.1014

MOUSA, E., H. MONZALY, I. SHAAT, A. ASHMAWY (2013): Factors affecting birth and weaning weights of native Farafra lambs in upper Egypt. EJSGS 8, 1-10.

DOI: $10.12816 / 0005042$
MURPHY, T. W., J. W. KEELE, B. A. FREKING (2020): Genetic and nongenetic factors influencing ewe prolificacy and lamb body weight in a closed Romanov flock. J. Anim. Sci. 98, 1-8.

DOI:10.1093/jas/skaa283

NOTTER, D. R., R. F. KELLY, F. S. McCLAUGHERTY (1991): Effects of ewe breed and management system on efficiency of lamb production. II. Lamb growth, survival and carcass characteristics. J. Anim. Sci. 69, 22-33.

DOI: $10.2527 / 1991.69122 x$

PETROVIĆ, M. P., D. RUŽIĆ MUSLIĆ, N. MAKSIMOVIĆ, N. MEMIŠI (2009): Effect of environmental and pargenetic factors on birth mass variability of Mis sheep populations. Biotechnol. Anim. Husb. 25, 213-219.

DOI:10.2298/BAH0904213P

PETROVIĆ, M. P., D. RUŽIĆ - MUSLIĆ, V. CARO PETROVIĆ, N. MAKSIMOVIĆ (2011): Influence of environmental factors on birth weight variability of indigenous Serbian breeds of sheep. Afr. J. Biotechnol. 10, 4673-4676.

DOI:10.5897/AJB10.2189

RAHIMI, S. M., S. A. RAFAT, S. JAFARI (2014): Effects of environmental factors on growth traits in Makuie sheep. Biotechnol. Anim. Husb. 30, 185-192.

DOI:10.2298/ BAH1402185R

SAFARI, E., N. M. FOGARTY, A. R. GILMOUR (2005): A review of genetic parameter estimates for wool, growth, meat and reproduction traits in sheep. Livest. Prod. Sci. 92, 271-289.

DOI:10.1016/j.livprodsci.2004.09.003

STATISTICA (2020): TIBCO Software Inc., v. 13.5.0, Palo Alto, CA, USA.

SUŠIĆ, V., V. PAVIĆ, B. MIOČ, I. ŠTOKOVIĆ, A. EKERT KABALIN (2005): Seasonal variations in lamb birth weight and mortality. Vet. arhiv 75, 375-381.

THIRUVENKADAN, A. K., M. DAHRAN, K. KARUNANITHI (2008): Effect of non-genetic factors on birth weight of Mecheri sheep of India. Livestock Res. Rural Dev. 20.

WOLFOVÁ, M., J. WOLF, M. MILERSKI (2011): Economic weights of production and functional traits for Merinolandschaf, Romney, Romanov and Sumavska sheep in the Czech Republic. Small Rumin. Res. 99, 25-33.

DOI: 10.10167j.smallrumres.2011.03.054 
VLAHEK, I., A. EKERT KABALIN, S. MENČIK, M. MAURIĆ MALJKOVIĆ, A. PIPLICA, H. KABALIN, J. ŠAVORIĆ, V. SUŠIĆ: Utjecaj negenskih čimbenika na porođajnu masu janjadi romanovske pasmine. Vet. arhiv 91, 615-624, 2021.

\section{SAŽETAK}

Cilj ovog istraživanja bio je analizirati negenske čimbenike porođajne mase janjadi romanovske pasmine i utvrditi koji od njih mogu biti korisni izvori informacija u selekciji ženskog rasplodnog podmlatka. U istraživanje je uključeno 1712 janjadi rođene u razdoblju od 2016. do 2019. godine. Za utvrđivanje utjecaja negenskih čimbenika na porođajnu masu korišten je model koji je uključivao tip rođenja, spol, redoslijed legla, godinu rođenja, sezonu rođenja i pripusnu skupinu kao fiksne čimbenike. Svi čimbenici osim sezone rođenja znakovito su utjecali na porođajnu masu $(\mathrm{P}<0,05)$. Faktori s najvećim učinkom na isto svojstvo bili su tip janjenja, spol i redni broj janjenja. Porođajna masa znakovito se smanjivala s porastom broja janjadi u leglu te su jedinci, dvojke, trojke i četvorke imali prosječnu porođajnu masu kako slijedi: 4,11 $\pm 0,07,3,56 \pm 0,05,3,07 \pm 0,05$ i 2,66 $\pm 0,08 \mathrm{~kg}$. Muška janjad $(3,44 \pm 0,05)$ bila je znakovito $(\mathrm{P}<$ $0,05)$ teža od ženske $(3,25 \pm 0,05)$. Najlakša janjad $(2,99 \pm 0,05)$ rođena je u prvom leglu, nakon čega se porođajna masa postupno povećavala do šestog legla $(3,54 \pm 0,10)$. Ukupna masa legla pokazivala je nelinearan porast s porastom broja janjadi u leglu $(\mathrm{P}<0,05)$. Ženska janjad iz legala dvojaka i trojaka nije se statistički znakovito razlikovala $(\mathrm{P}>$ $0,05)$ s obzirom na udio ženske i muške janjadi u leglu. Razlike između porođajne mase ženki iz legla dvojaka i ženki iz legla trojaka bile su statistički znakovite $(\mathrm{P}<0,05)$. Na varijacije u porođajnoj masi utječu negenski čimbenici među kojima se ističu tip janjenja, spol i redoslijed legla. To treba uzeti u obzir u provedbi uzgojno-selekcijskog rada u kojemu se primarna pozornost posvećuje svojstvima plodnosti i rasta.

Ključne riječi: porođajna masa; masa legla; negenski čimbenici; romanovska ovca; selekcija 